\title{
Left Atrial Volume Index (LAVI) as a Predictor of Outcome for First Time ST Elevation Myocardial Infarction (STEMI), Compared to Other Conventional Echocardiographic Parameters of Left Ventricular (LV) Function
}

\author{
MOHAMED M.R. ABD EL-AZIZ, M.Sc.; KHALED M. EL-MAGHRABY, M.D.; \\ HAMDY Sh. MOHAMMAD, M.D. and YEHIA T. KISHK, M.D.
}

The Department of Cardiovascular Medicine, Faculty of Medicine, Assiut University

\begin{abstract}
Background: Acute Heart Failure (AHF) complicates acute Myocardial Infarction (AMI) as a result of complex interaction of structural, hemodynamic, neurohormonal, and genetic maladaptations. This study aims to analyse the role of Left Atrial Volume Index (LAVI) compared to other conventional parameters of systolic and diastolic Left Ventricular function (LV) in patients with first time ST Segment Elevation Myocardial Infarction (STEMI), in predicting in-Hospital Heart failure (HF), in-hospital mortality and development of heart failure and subsequent rehospitalisation over a followup period of 6 months.
\end{abstract}

Material and Methods: The present study is a prospective observational study conducted in the Cardiology Department of Assiut University Hospitals (AUH) on 70 STEMI patients admitted to Coronary Care Unit (CCU). Left Ventricular Ejection Fraction (LVEF), LV End-Systolic and End-Diatolic Dimensions (LVESD and LVEDD), LAVI, diastolic and systolic parameters were measured within 24 hours after admission and then 6 months later. These variables were correlated with the development of heart failure according to Killip classification on admission and 6 months later by NYHA classification.

Results: There was a statistically significant difference regarding development of in-hospital HF (Killip classification $>$ II) with the following variables LAV, LAVI, LVESD, FS, $\mathrm{EF}$, and the diastolic parameters used to evaluate diastolic function except Isovolumetric Relaxation Time (IVRT) and E/A ratio, whereas in-hospital mortality was related significantly to the same variables except LAVI, E/A ratio and EF by univariate analysis. ( $p$-value $<0.001)$.

After 6 months of follow-up, there was a statistically significant relation between mortality development and the following variables; LAVI, EF, Deceleration Time (DT), IVRT, TDI (tissue Doppler imaging) septal e` and E/e` by univariate analysis. $(p$-value $<0.001)$.

A statistically significant correlation between development of HF symptoms according to NYHA classification and

Correspondence to: Dr. Mohamed M.R. Abd El-Aziz, E-Mail: mreda30688@.gmail.com subsequent rehospitalization was observed with the previously mentioned variables except DT and IVRT by univariate analysis. ( $p$-value $<0.001)$.

LAVI, EF, TDI septal é and E/é ratio had a statistically significant correlation with development of in-hospital HF ( $p$-value $<0.001)$, but only E/é ratio and TDI septal e' were significantly related to in-hospital mortality $(p$-value $<0.05$ ). All the previously mentioned four variables were significant predictors of mortality or symptoms of $\mathrm{HF}$ and rehospitalization over six months follow-up. ( $p$-value $<0.05$ ).

Using multiple regression analysis, LAVI $\mathrm{ml} / \mathrm{m}^{2}, \mathrm{E} / \mathrm{e}$ ratio, EF were the most significant predictors of in-hospital $\mathrm{HF}$ with $\mathrm{E} / \mathrm{e}^{\prime}$ ratio being the most powerful predictor. ( $p$ value $=0.001$ ) and LAVI $\mathrm{ml} / \mathrm{m}^{2}$ was the most powerful predictor of mortality during the follow up period. $(p$-value $=0.03)$.

Conclusions: LAVI and other determinants of systolic and diastolic functions of the heart played an important role in prediction of HF and mortality both in the in-hospital setting and after a follow-up period of 6 months.

LAVI, E/e ratio and EF are the most significant predictors of in hospital heart failure with $\mathrm{E} / \mathrm{e}^{\prime}$ ratio being the most powerful predictor, LAVI and EF were the most powerful predictors of mortality and HF during a follow-up period of 6 months respectively.

Key Words: STEMI - Killip - Left ventricle diastolic dysfunction - LAVI.

\section{Introduction}

MYOCARDIAL Infarction (MI) can be recognized by clinical features, including Electrocardiographic (ECG) findings, elevated values of biochemical markers of myocardial necrosis, and by imaging, or may be defined by pathology. It is a major cause of death and disability worldwide [1]

Myocardial ischemia induced by exercise or pharmacological stress causes myocardial dysfunc- 
tion. In response to acute ischemia, diastolic dysfunction develops before systolic dysfunction becomes apparent. Thus, it is not surprising that stress-induced diastolic dysfunction has been repeatedly reported to be a more sensitive determinant for detection of Coronary Artery Disease (CAD) than measuring systolic dysfunction [2-6]

The presence of diastolic dysfunction in patients with CAD with MI, Acute Coronary Syndrome (ACS), and chronic stable CAD has a prognostic impact regarding future events [7]. The presence of diastolic dysfunction in patients who have suffered an MI indicates a poor prognosis with a higher risk of in-hospital or early mortality and more marked Left Ventricular (LV) remodelling $[8,9]$.

LV systolic function has been extensively studied in relation to development of HF; however it has now become apparent that LV diastolic function contributes to symptoms and signs of clinical Heart Failure (HF) [10]

Other echocardiographic parameters like Left Atrial Volume (LAV) and diastolic indices like E/A ratio, Deceleration Time (DT) are believed to be useful in predicting early in-hospital HF in patients with ST elevation MI (STEMI) [10]

This study aims to analyze the role of LAV compared to other conventional parameters of systolic and diastolic LV function in patients with first time STEMI, in predicting in-hospital HF, inhospital mortality and development of HF, rehospitalization and mortality over a follow-up period of 6 months.

\section{Material and Methods}

The present study is a prospective observational study conducted in the Cardiology Department of Assiut University Hospitals (AUH) on 70 STEMI patients admitted to Coronary Care Unit (CCU) between 1 st of February 2016 and $30^{\text {th }}$ of June 2016. They were all qualified after exclusion criteria.

We excluded patients with prior history of non STEMI, early reinfarction, previous Coronary Bypass (CABG), valvular heart disease, congenital heart disease, left bundle branch block, chronic HF.

\section{Demographic, medical and laboratory data:}

Demographic and medical data including age, gender, smoking, Diabetes Mellitus (DM), Hypertension (HTN), renal insufficiency, previous MI,
Percutaneous Intervention (PCI) or CABG, family history and dyslipidemia.

The Body Mass Index (kg/m2) (BMI) and body surface area $\left(\mathrm{m}^{2}\right)$ were calculated.

\section{Clinical examination stressing on:}

Blood pressure, Pulse, cardiac examination, and Killip class [11] also recorded.

Clinical examination of the patients was repeated 6 months later with additional assessment of symptoms of heart failure using New York Heart Association (NYHA) classification [12] .

\section{Management strategies:}

ACS subdivided into three subgroup patient with acute MI, whose underwent different management strategies as primary PCI, received Streptokinase (SK), SK then rescue PCI and medical treatment.

\section{Laboratory investigations:}

All patients investigated with routine work up as cardiac enzymes (Troponin I $\mathrm{ng} / \mathrm{ml}$ ), urea nitrogen $(\mathrm{mg} / \mathrm{dl})$, creatinine $(\mathrm{mg} / \mathrm{dl})$, serum sodium $(\mathrm{mmol} / \mathrm{l})$, potassium levels $(\mathrm{mmol} / \mathrm{l})$, magnesium (mmol/l), lipid profile $\mathrm{mg} / \mathrm{dl}$, complete blood picture, Prothrombin Concentration (PC) and INR.

\section{Echocardiography:}

All patients were examined by transthoracic Doppler echocardiography (Phillips i.e. 33 ultrasound system device) within 24 hours of admission using the following protocol:

- With M-mode, LV Ejection Fraction (EF), LV dimensions, diastolic and systolic dimensions were measured. Segmental wall motion defects were assessed by 2-dimensional echocardiography [13]

- LAV calculated, using an area length formula, (Equation 1) [13]

Equation 1: Shows area length formula to calculate LAV and LAVI:

$$
\begin{aligned}
& \begin{array}{l}
\text { Left artial volume } \\
(\text { LAV) } \mathrm{ml}
\end{array}=\frac{8}{3 \pi}\{\} \\
& \text { Left artial volume (LAV) } \mathrm{ml} \\
& \begin{array}{l}
\text { Left artial volume } \\
\text { index }(\text { LAV }) \mathrm{ml} / \mathrm{m}^{2}
\end{array}=\text { Body surface area (BSA) } \mathrm{m} 2
\end{aligned}
$$

The area length A1 and A2 measured in apical four chambers (A4C) view and apical two chambers (A2C) view respectively, by tracing the area of LA. Length (L) is defined as the shortest of the 
two long axes measured in the $\mathrm{A} 4 \mathrm{C}$ view and $\mathrm{A} 2 \mathrm{C}$ view at ventricular end-systole.

- Grading of diastolic dysfunction (LVDD): Patients who had LVDD was classified into three grades accordingly [14]:

- Grade 1:Prolonged relaxation pattern.

- Grade 2: Pseudo-normalization pattern; and.

- Grade 3: Restrictive pattern.

The following diastolic parameters was used for grading $L V$ diastolic function:

- Pulsed Doppler mitral flow velocity (E, A, E/A ratio, and deceleration time of early filling (DT), and the Isovolumic Relaxation Time (IVRT).

- Tissue Doppler Imaging (TDI) (e` and a`velocity at septal mitral valve annulus).

- The Valsalva manoeuvre was done if needed to confirm the grade of LVDD.

\section{Statistical analysis:}

The data were tested for normality using the Anderson-Darling test and for homogeneity variances prior to further statistical analysis. Categorical variables were described by number and percent $(\mathrm{N}, \%)$, where continuous variables were described by mean and standard deviation (mean \pm SD). Chisquare test and Fisher exact test were used to compare between categorical variables whereas comparison was done between continuous variables by $t$-test and ANOVA. Pearson correlation coefficients were used to assess the correlation between continuous variables. Multiple regression analysis was used for multivariate analysis. A two-tailed $p$ $<0.05$ was considered statistically significant. All analyses were performed with the IBM SPSS 20.0 software.

Informed oral consent was obtained from all participants after explanation of all steps of the study. It was explained to all the participants that the collected data is confidential and for the purpose of the scientific research only, all investigations regarding electrocardiographic, echocardiographic and, laboratory investigations were free without any cost to the participant, any faulty habits towards treatment and lifestyle modification were advised through health education by the researcher himself. The Ethical Committee of Assiut Faculty of Medicine approved the study.

\section{Results}

A total of 70 patients were included in this study, who were admitted in Cardiology Department of Assiut University Hospital, they presented with acute STEMI, 54 patients $(77.1 \%)$ were males with a mean age of $55.6 \pm 13.1$ years. Diabetics were $(35.7 \%)$, hypertensives were $(21.4 \%)$ and $62.8 \%$ were smokers.

Table (1): Baseline characteristics of patients.

\begin{tabular}{|c|c|c|}
\hline & No. & $\%$ \\
\hline \multicolumn{3}{|l|}{ Age: } \\
\hline Range & \multicolumn{2}{|c|}{$20-85$} \\
\hline Mean \pm SD & \multicolumn{2}{|c|}{$55.6 \pm 13.1$} \\
\hline \multicolumn{3}{|l|}{ Gender: } \\
\hline Male & 54 & 77.1 \\
\hline Female & 16 & 22.9 \\
\hline \multicolumn{3}{|l|}{ BMI: } \\
\hline Range & \multicolumn{2}{|c|}{$18.8-41.5$} \\
\hline Mean \pm SD & \multicolumn{2}{|c|}{$27.9 \pm 4.5$} \\
\hline \multicolumn{3}{|l|}{ Smoking: } \\
\hline Yes & 44 & 62.9 \\
\hline No & 26 & 37.1 \\
\hline \multicolumn{3}{|l|}{$D M:$} \\
\hline Yes & 25 & 35.7 \\
\hline No & 45 & 64.3 \\
\hline \multicolumn{3}{|l|}{$H T N:$} \\
\hline Yes & 15 & 21.4 \\
\hline No & 55 & 78.6 \\
\hline \multicolumn{3}{|l|}{ Previous IHD: } \\
\hline Yes & 10 & 14.3 \\
\hline No & 60 & 85.7 \\
\hline \multicolumn{3}{|l|}{ Family history: } \\
\hline Yes & 4 & 5.7 \\
\hline No & 66 & 94.3 \\
\hline \multicolumn{3}{|l|}{ History of dyslipidemia: } \\
\hline Yes & 3 & 4.3 \\
\hline No & 67 & 95.7 \\
\hline \multicolumn{3}{|l|}{ Diagnosis: } \\
\hline Anterior MI & 14 & 20.0 \\
\hline Extensive anterior MI & 27 & 38.6 \\
\hline Extensive inferior MI & 12 & 17.1 \\
\hline Inferior MI & 15 & 21.4 \\
\hline Lateral MI & 2 & 2.9 \\
\hline \multicolumn{3}{|l|}{ Management strategy: } \\
\hline PPCI & 33 & 47.1 \\
\hline Ant ischemic & 2 & 2.9 \\
\hline SK & 35 & 50.0 \\
\hline \multicolumn{3}{|l|}{ Killip class: } \\
\hline I & 37 & 52.9 \\
\hline II & 10 & 14.3 \\
\hline III & 20 & 28.6 \\
\hline IV & 3 & 4.3 \\
\hline
\end{tabular}

Patients who received thrombolysis by SK were $35(50 \%)$, while 33 patients underwent primary PCI $(47.1 \%)$ and only two patients had neither due to late presentation. 
The number of patients who developed in hospital HF with Killip class >II were 23 (32.9\%), 20 of them being in class III (28.6\%) and $3(4 \%)$ patients in class IV. A total of four patients died during admission where in-hospital mortality of $5.7 \%$.

On follow-up 6 months later, further seven patients died due to cardiac causes $(10 \%)$ and twenty patients were admitted again within six months due to cardiac causes (development of heart failure and new ischemic insult).

There was a statistically significant correlation regarding development of in-hospital heart failure (Killip classification >II) with the following variables:

LAV, LAVI, LVESD, EF, and the diastolic parameters used to evaluate diastolic function.

However, there was a statistically significant correlation regarding development of in-hospital mortality with the same variables except LAVI, $\mathrm{E} / \mathrm{A}$ ratio and $\mathrm{EF}$.

Six months later, follow-up of our patients revealed a statistically significant correlation be- tween mortality development and the following variables:

LAVI, EF, E/A ratio, DT, IVRT, TDI Septal e', E/e'

Also, a statistically significant correlation between development of HF symptoms according to NYHA classification and subsequent rehospitalization and the following variables; LAVI, EF, E/A ratio, TDI septal é and E/é ratio.

It was found that LAVI correlated significantly with other echocardiographic indices of systolic and diastolic function using Pearson correlation coefficients.

LAVI $\mathrm{ml} / \mathrm{m}^{2}$, E/e' ratio, EF were the most significant predictors of in-hospital heart failure with E/e ratio being the most powerful predictor and LAVI was the most powerful predictor of mortality over that period.

However, EF appeared to be the most important predictor of development of symptoms of heart failure and need for rehospitalization over the same follow-up period.

Table (2): Effect of different echocardiographic variables on Killip classification grading on admission

\begin{tabular}{|c|c|c|c|c|c|}
\hline & \multicolumn{4}{|c|}{ Killip class } & \multirow{2}{*}{$\begin{array}{c}p- \\
\text { value }\end{array}$} \\
\hline & $\begin{array}{c}I(n=37) \\
\text { Mean } \pm S D\end{array}$ & $\begin{array}{c}\mathrm{II}(\mathrm{n}=10) \\
\text { Mean } \pm \mathrm{SD}\end{array}$ & $\begin{array}{c}\text { III }(n=20) \\
\text { Mean } \pm \text { SD }\end{array}$ & $\begin{array}{c}\text { IV }(n=3) \\
\text { Mean } \pm \text { SD }\end{array}$ & \\
\hline Left atrium A1 & $15.5 \pm 2.9$ & $17 \pm 4.9$ & $20.3 \pm 2.9$ & $20.3 \pm 2.1$ & $0.000 * *$ \\
\hline Lt atrium A2 & $15.4 \pm 3.2$ & $17.2 \pm 4.6$ & $20.4 \pm 3.4$ & $21 \pm 3.6$ & $0.000 * *$ \\
\hline $\mathrm{LAV} \mathrm{ml}$ & $47.7 \pm 13.4$ & $60.8 \pm 25.4$ & $77.9 \pm 16.4$ & $78.2 \pm 13.4$ & $0.000 * *$ \\
\hline $\mathrm{LAVI} \mathrm{ml} / \mathrm{m}^{2}$ & $24.6 \pm 7.3$ & $26.9 \pm 10.3$ & $36.2 \pm 3.9$ & $38.9 \pm 4.9$ & $0.000 * *$ \\
\hline LV ESD & $3.6 \pm 0.5$ & $3.7 \pm 0.5$ & $4.1 \pm 0.6$ & $4.2 \pm 0.7$ & $0.002 * *$ \\
\hline FS & $27.9 \pm 5.1$ & $25.5 \pm 6.3$ & $22 \pm 3.9$ & $23.3 \pm 6$ & $0.001 * *$ \\
\hline $\mathrm{EF}$ & $52.4 \pm 7$ & $46.2 \pm 11.8$ & $41.6 \pm 6.5$ & $44.7 \pm 10.3$ & $0.000 * *$ \\
\hline $\mathrm{E} / \mathrm{A}$ ratio & $0.9 \pm 0.3$ & $1.1 \pm 0.5$ & $1.5 \pm 0.9$ & $1.4 \pm 0.7$ & $0.012 *$ \\
\hline DT & $209.3 \pm 25.7$ & $195.7 \pm 26.9$ & $175.5 \pm 28.7$ & $166.7 \pm 23.1$ & $0.000 * *$ \\
\hline IVRT & $93.9 \pm 18.3$ & $82 \pm 19.3$ & $84.5 \pm 18.6$ & $70 \pm 10$ & $0.046^{*}$ \\
\hline TDI Septal e’ & $7.5 \pm 1.6$ & $6.3 \pm 1$ & $6 \pm 0.9$ & $5.1 \pm 0.4$ & $0.000 * *$ \\
\hline $\mathrm{E} / \mathrm{e}^{\prime}$ & $7.9 \pm 2$ & $9.9 \pm 3.5$ & $13.2 \pm 3.1$ & $14.9 \pm 4.5$ & $0.000 * *$ \\
\hline \multicolumn{6}{|c|}{$\begin{array}{ll}\text { LAV } & \text { : Left Atrial Volume. } \\
\text { LAVI } & \text { : Left Atrial Volume Index. } \\
\text { LVESD } & \text { : Left Ventricular Endsystolic Dia } \\
\text { FS } & \text { : Fractional Shortening. } \\
\text { EF } & \text { : Ejection Fraction. } \\
\text { DT } & \text { : Deceleration Time. } \\
\text { IVRT } & \text { : Isovolumetric Relaxation Time. } \\
\text { TDI } & \text { : Tissue Doppler Imaging. }\end{array}$} \\
\hline
\end{tabular}


Table (7): Multivariate analysis to assess the most powerful predictors of Killip classification.

\begin{tabular}{llll}
\hline & Beta & $t$ & $p$-value \\
\hline LAVI ml $/ \mathrm{m}^{2}$ & 0.28 & 2.43 & $0.018^{*}$ \\
EF & -0.24 & -2.44 & $0.017^{*}$ \\
E/A ratio & -0.18 & -1.32 & 0.191 \\
TDI Septal e & 0.09 & 0.71 & 0.479 \\
E/e & 0.76 & 4.10 & $0.001^{* *}$ \\
DT & 0.23 & 1.50 & 0.139 \\
\hline
\end{tabular}

LAV : Left Atrial Volume.

LAVI : Left Atrial Volume Index.

EF : Ejection Fraction.

DT : Deceleration Time.

TDI : Tissue Doppler Imaging.

Table (8): Multivariate analysis to assess the most powerful predictors of mortality follow-up.

\begin{tabular}{llc}
\hline & ODDS $(95 \% \mathrm{CI})$ & $p$-value \\
\hline LAVI ml/m & $0.68(0.48-0.96)$ & $0.030 *$ \\
EF & $0.98(0.84-1.14)$ & 0.756 \\
E/A ratio & $1.31(0.14-11.84)$ & 0.811 \\
TDI Septal e & $1.36(0.26-7.2)$ & 0.714 \\
E/e & $0.62(0.36-1.06)$ & 0.081 \\
DT & $0.97(0.91-1.03)$ & 0.334 \\
\hline
\end{tabular}

LAV : Left Atrial Volume.

LAVI : Left Atrial Volume Index.

EF : Ejection Fraction.

DT : Deceleration Time.

TDI : Tissue Doppler Imaging.

Table (9): Multivariate analysis to assess the most powerful predictors of NYHA class and rehospitalization.

\begin{tabular}{lccc}
\hline & Beta & $t$ & $p$-value \\
\hline LAVI ml/m & 0.24 & 1.60 & 0.115 \\
EF & -0.36 & -2.77 & $0.008 * *$ \\
E/A ratio & 0.21 & 1.29 & 0.204 \\
TDI Septal e' & -0.23 & -1.52 & 0.134 \\
E/e & -0.12 & -0.51 & 0.614 \\
DT & 0.02 & 0.13 & 0.900 \\
\hline LAV : Left Atrial Volume. & & \\
LAVI : Left Atrial Volume Index. & & \\
EF : Ejection Fraction. & \\
DT : Deceleration Time. & \\
TDI : Tissue Doppler Imaging. & &
\end{tabular}

\section{Discussion}

The main purpose of this study was to analyse the role of LAVI compared to other conventional parameters of systolic and diastolic LV function in patients with first time STEMI, in predicting early $\mathrm{HF}$ and mortality during in-hospital evolution by echocardiography.

LV diastolic dysfunction progresses due to progressive LV remodelling after AMI and leads to a rise in LV End Diastolic Pressure (LVEDP). Because the left atrium is influenced by LVEDP while the mitral valve is open, LA pressure increas- es due to the persistent rise of LVEDP, and LAVI increases. After AMI progressive diastolic dysfunction due to LV remodelling and increasing LVEDP have been reported to indicate a poor prognosis [15].

Alashetty et al., analyzed the role of LAVI compared to other conventional parameters of systolic and diastolic LV function in patients with first time STEMI, in predicting early HF during in-hospital evolution by echocardiography [16] Their results analyzed LAVI, the mean LAVI in patients with HF Killip > II was $28.96 \mathrm{ml} / \mathrm{m}$ and those without HF was $22.55 \mathrm{ml} / \mathrm{m}$ which was statistically significant $(p$ 0.01) [16]

Likewise, our study showed elevated LAVI in patients with Killip class III and IV, it had a mean value of $36.2 \pm 3.9$ in patients with Killip class III patients and $38.9 \pm 4.9$ in Killip class IV patients compared to $24.6 \pm 7.3$ in Killip class I patients and $26.9 \pm 10.3$ in Killip class II patients. The relation was statistically significant with $p$-value $<0.001$.

Souza et al., did not observe any significant result between HF and LAVI with a mean LAVI of $18.7 \pm 4.8$ in patients with no CHF, and 20.6 \pm 5.7 in patients with CHF following first STEMI with $p$-value of 0.1 [17].

This difference may be attributed to the fact that in that study, LA volume Index was not significantly different between patients with or without $\mathrm{CHF}$ in the univariate analysis. This result was expected, since LA remodeling could not occur within 48 hours of initial presentation of a first AMI, because it is not a marker of acute changes in diastolic function and/or increased filling pressures and echocardiographic examination was performed within 30 hours of onset of chest pain [10].

Moller et al., also analyzed the role of LAVI and other indices of diastolic and systolic function after AMI in 314 patients, they observed a significant association between LAVI and Killip class with a $p$-value $<0.001$ [18]

In our study, LAVI was not significantly related to development of in-hospital mortality with a mean of $36.8 \pm 1.9$ in patients who died during admission and $28.4 \pm 8.8$ in patients who didn't and a $p$-value of 0.059 .

This result is not correspondent with other studies analyzing the role of LAVI as a predictor of mortality following AMI, for example Moller et al., in 2003 concluded that LAVI is a predictor 
of survival after AMI [18]. Furthermore, LAVI provides prognostic information incremental to clinical data and standard echocardiographic predictors of outcome. They had a mean of LAVI of more than $32 \mathrm{~mL} / \mathrm{m}^{2}$ in 104 out of 268 surviving patient and 38 out of 46 deceased patients following AMI with a $p$-value of 0.001 , this difference might be due to the smaller size of our research sample of patients and the fact that Moller's study included all-cause mortality over a median follow-up period of 15 months.

However, LAVI was an important predictor of subsequent development of heart failure symptoms and rehospitalization due to cardiac causes after a follow-up of 6 months with a mean value of $36.6 \pm 7$ in patients with NYHA class III symptoms, 33.2 \pm 7 in patients with NYHA class II symptoms and $25.3 \pm 7.9$ in patients with NYHA class I, $p$-value was $<0.001$. LAVI had a mean value of $36.7 \pm 7.2$ in patients who were admitted due to cardiac causes and $25 \pm 6.8$ in patients who were not with a $p$-value of $<0.001$.

Many studies analyzed the role of EF as a predictor for in hospital HF like Alashetty et al., in 2014 showed that EF is a powerful index of systolic function and also its role in predicting in hospital heart failure has been well established [16].

Mean EF in patients with CHF present was $36 \%$ and in those without CHF was $45 \%$, which was statistically significant $p<0.001$ [16].

Souza et al., in their 2011 study concluded that $\mathrm{EF}<40 \%$ was a powerful independent variable associated with development of CHF killip >II with a mean of $0.51 \pm 0.07$ in patients with no CHF and $0.44 \pm 0.07$ in patients with $\mathrm{CHF}$ ( $p$-value $<0.001$ ), it was superior to other indices of systolic and diastolic function [17]

Poulsen et al., also observed that EF $<45 \%$ was significant prognostic parameter in assessing $\mathrm{LV}$ function and predicting in hospital $\mathrm{HF}$ with mean EF of $50 \pm 10$ in patients without CHF and $41 \pm 10$ in patients with CHF following first acute STEMI [19].

Our study confirmed the previous data with EF having a statistically significant relation with development of in hospital HF with mean values of $52.4 \pm 7$ and $46.2 \pm 11.8$ in Killip I and Killip II patients respectively, and $41.6 \pm 6.5$ and $44.7 \pm 10.3$ in patients with Killip III and IV patients respectively and a $p$-value of $<0.0001$.
However, EF doesn't appear to be a significant predictor of in hospital mortality with a mean of $46.3 \pm 6.7$ in patients with in hospital mortality, and $48.2 \pm 9.2$ in surviving patients $(p$-value $=0.68$ ).

Of course, EF played an important role as a predictor of mortality over a follow-up period of 6 months with a mean \pm SD value of $42.2 \pm 6$ in patients who died within this period and 49.2 \pm 9.1 in surviving patients. ( $p$-value $=0.017)$. It also predicted development of HF symptoms and rehospitalization due to cardiac causes with follow-up with a mean \pm SD value of $39.2 \pm 6.2$ in NYHA III patients, 46.6 \pm 11.2 in NYHA II patients and 58.2 \pm 7 in NYHA I patients. ( $p$-value $<0.001)$. It had a mean \pm SD value of $41.4 \pm 8$ in patients who were admitted due to cardiac causes and $57.8 \pm 7.6$ in patients who were not with a $p$-value of $<0.001$.

DT is an important determinant of diastolic function, Alashetty et al., demonstrated that Deceleration time (DT) showed a significant association with a presence of heart failure ( $p$-value 0.04) [16] Souza et al., observed no significant association between DT and heart failure (killip >II) [17] whereas Poulsen et al., found that a DT of $<130 \mathrm{~ms}$ identified a risk of developing HF [19]

Our study showed that DT had a statistically significant relation with development of in-hospital $\mathrm{HF}$ with mean $\pm \mathrm{SD}$ values of $209.3 \pm 25.7$ and $195.7 \pm 26.9$ in Killip I and Killip II patients respectively, and $175.5 \pm 28.7$ and $166.7 \pm 23.1$ in patients with Killip III and IV patients respectively, and a $p$-value of $<0.0001$. It was also a significant predictor of in-hospital mortality with a mean \pm SD of $162.5 \pm 20.6 \mathrm{in}$ patients with in-hospital mortality, and $197.9 \pm 30$ in surviving patients $(p$-value $=0.024)$.

DT played an important role as a predictor of mortality over a follow-up period of 6 months with a mean \pm SD value of $171.8 \pm 24$ in patients who died within this period and $200.3 \pm 29.7$ in surviving patients. $(p$-value $=0.004)$.

It also predicted development of HF symptoms and rehospitalisation due to cardiac causes with follow-up with a mean \pm SD value of $175 \pm 33.5$ in NYHA III patients, $215.7 \pm 58.9$ in NYHA II patients, and 209.6 \pm 19 in NYHA I patients. ( $p$-value $=0.007)$. It had a mean \pm SD value of $183.3 \pm 31$ in patients who were admitted due to cardiac causes, and $215.2 \pm 33.4$ in patients who were not with a $p$ value of $<0.001$.

E/é ratio had a statistically significant relation with development of in-hospital HF with mean \pm SD values of $7.9 \pm 2$ and $9.9 \pm 3.5$ in Killip I and 
Killip II patients respectively, and $13.2 \pm 3.1$ and $14.9 \pm 4.5$ in patients with Killip III and IV patients respectively and a $p$-value of $<0.001$.

It was also a significant predictor of in-hospital mortality with a mean \pm SD of $16.8 \pm 2.1$ in patients with in hospital mortality and $9.6 \pm 3.3$ in surviving patients ( $p$-value $<0.001$ ).

E/é ratio played an important role as a predictor of mortality over a follow-up period of 6 months with a mean \pm SD value of $14.1 \pm 3.7$ in patients who died within this period and $9.2 \pm 3.1$ in surviving patients. ( $p$-value <0.001).

It predicted development of heart failure symptoms admission due to cardiac causes with followup with a mean \pm SD value of $12.6 \pm 3.5$ in NYHA III patients, $9.8 \pm 3.9$ in NYHA II patients, and $8.6 \pm 2.7$ in NYHA I patients. ( $p$-value $=0.002)$. It had a mean \pm SD value of $11.7 \pm 3.8$ in patients who were admitted due to cardiac causes and $8.6 \pm 2.6$ in patients who were not with a $p$-value of $<0.001$.

\section{Conclusions:}

LAVI, E/e' ratio and EF are the most significant predictors of in hospital heart failure with E/e ratio being the most powerful predictor.

LAVI was the most powerful predictor of mortality follow-up period and EF is the most important predictor of development of symptoms of heart failure over the same follow-up period.

\section{Conflicts of interest notification:}

The authors have no conflicts of interest to declare.

\section{Acknowledgment:}

A special thank you to everyone who made this study possible: Prof. Dr. Yehia Taha Kishk, M.D., Ph.D., Dr. Hamdy Shams Eddin Mohammad, M.D., Ph.D., Dr. Khaled Mohamed El-Maghraby, M.D., $\mathrm{Ph} . \mathrm{D}$, and everyone within the Cardiology Department of Assiut University Hospital who assisted with the whole process of this work.

\section{Funding:}

No funding.

\section{References}

1- THYGESEN K., ALPERT J.S., JAFFE A.S., SIMOONS M.L., CHAITMAN B.R., WHITE H.D., et al.: Third universal definition of myocardial infarction. J. Am. Coll. Cardiol., 60 (16): 1581-98, 2012.

2- TSOUGOS E., PANOU F., PARASKEVAIDIS I., DAGRES N., KARATZAS D. and KREMASTINOS D.T.:
Exercise-induced changes in E/E' ratio in patients with suspected coronary artery disease. Coron. Artery Dis., 19 (6): 405-11, 2008.

3- ISHII K., IMAI M., SUYAMA T., MAENAKA M., NAGAI T., KAWANAMI M., et al.: Exercise-induced postischemic left ventricular delayed relaxation or diastolic stunning: Is it a reliable marker in detecting coronary artery disease? J. Am. Coll. Cardiol., 53 (8): 698-705, 2009.

4- NAKAJIMA Y., KANE G.C., McCULLY R.B., OMMEN S.R. and PELLIKKA P.A.: Left ventricular diastolic filling pressures during dobutamine stress echocardiography: Relationship to symptoms and ischemia. J. Am. Soc. Echocardiogr., 22 (8): 947-53, 2009.

5- HOFFMANN S., MOGELVANG R., OLSEN N.T., SOGAARD P., FRITZ-HANSEN T., BECH J., et al.: Tissue Doppler echocardiography reveals distinct patterns of impaired myocardial velocities in different degrees of coronary artery disease. Eur. J. Echocardiogr., 11 (6): 544-9, 2010.

6- PARASKEVAIDIS I.A., TSOUGOS E., PANOU F., DAGRES N., KARATZAS D., BOUTATI E., et al.: Diastolic stress echocardiography detects coronary artery disease in patients with asymptomatic type II diabetes. Coro.n Artery Dis., 21 (2): 104-12, 2010.

7- OHARA T. and LITTLE W.C.: Evolving focus on diastolic dysfunction in patients with coronary artery disease. Curr. Opin. Cardiol., 25 (6): 613-21, 2010.

8- MOLLER J.E., SONDERGAARD E., SEWARD J.B., APPLETON C.P. and EGSTRUP K.: Ratio of left ventricular peak E-wave velocity to flow propagation velocity assessed by color M-mode Doppler echocardiography in first myocardial infarction: Prognostic and clinical implications. J. Am. Coll. Cardiol., 35 (2): 363-70, 2000.

9- UENO Y., NAKAMURA Y., KINOSHITA M., FUJITA T., SAKAMOTO T. and OKAMURA H.: An early predictor of left ventricular remodeling after reperfused anterior acute myocardial infarction: Ratio of peak $\mathrm{E}$ wave velocity/flow propagation velocity and mitral $\mathrm{E}$ wave deceleration time. Echocardiography, 19 (7 Pt 1): 555-63, 2002

10- SOUZA L.P., CAMPOS O., PERES C.A., MACHADO C.V. and CARVALHO A.C.: Echocardiographic predictors of early in-hospital heart failure during first ST-elevation acute myocardial infarction: Does myocardial performance index and left atrial volume improve diagnosis over conventional parameters of left ventricular function? Cardiovasc Ultrasound, 9: 17, 2011.

11- KILLIP T., ${ }^{3 \mathrm{rd}}$ and KIMBALL J.T.: Treatment of myocardial infarction in a Coronary Care Unit. A two year experience with 250 patients. Am. J. Cardiol., 20 (4): 457-64, 1967.

12- New York Heart Association. Criteria Committee, New York Heart Association. Nomenclature and criteria for diagnosis of diseases of the heart and great vessels. $8^{\text {th }}$ ed. Boston: Little, Brown; XIII, 349 p.p, 1979.

13- LANG R.M., BADANO L.P., MOR-AVI V., AFILALO J., ARMSTRONG A., ERNANDE L., et al.: Recommendations for cardiac chamber quantification by echocardi- 
ography in adults: An update from the American Society of Echocardiography and the European Association of Cardiovascular Imaging. Eur. Heart J. Cardiovasc. Imaging, 16 (3): 233-70, 2015.

14-NAGUEH S.F., SMISETH O.A., APPLETON C.P, BYRD B.F., 3 rd, DOKAINISH H., EDVARDSEN T., et al.: Recommendations for the Evaluation of Left Ventricular Diastolic Function by Echocardiography: An Update from the American Society of Echocardiography and the European Association of Cardiovascular Imaging. J. Am. Soc. Echocardiogr., 29 (4): 277-314, 2016.

15- BOLOGNESE L., NESKOVIC A.N., PARODI G., CERISANO G., BUONAMICI P., SANTORO G.M., et al.: Left ventricular remodeling after primary coronary angioplasty: Patterns of left ventricular dilation and long-term prognostic implications. Circulation, 106 (18): 2351-7, 2002.

16-ALASHETTY A.S. and BADIGER S.: Echocardiographic predictors of early in-hospital heart failure during first
ST-elevation myocardial infarction. International Journal of Biomedical and Advance Research, 5 (1): 50-3, 2014.

17- SOUZA L.P., CAMPOS O., PERES C.A., MACHADO C.V. and CARVALHO A.C.: Echocardiographic predictors of early in-hospital heart failure during first ST-elevation acute myocardial infarction: Does myocardial performance index and left atrial volume improve diagnosis over conventional parameters of left ventricular function? Cardiovascular Ultrasound, 9 (1): 1, 2011.

18- MOLLER J.E., HILLIS G.S., OH J.K., SEWARD J.B., REEDER G.S., WRIGHT R.S., et al.: Left atrial volume: A powerful predictor of survival after acute myocardial infarction. Circulation, 107 (17): 2207-12, 2003.

19- POULSEN S.H., JENSEN S.E., GOTZSCHE O. and EGSTRUP K.: Evaluation and prognostic significance of left ventricular diastolic function assessed by Doppler echocardiography in the early phase of a first acute myocardial infarction. Eur. Heart J., 18 (12): 1882-9, 1997.

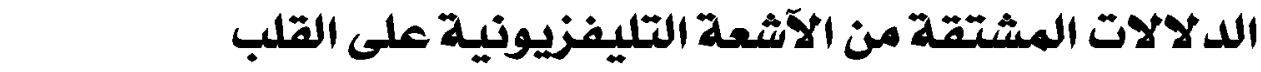

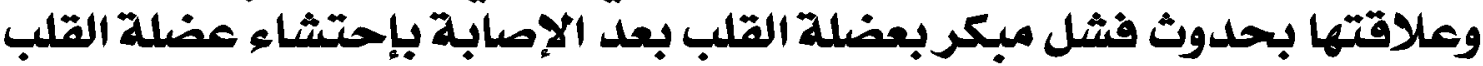

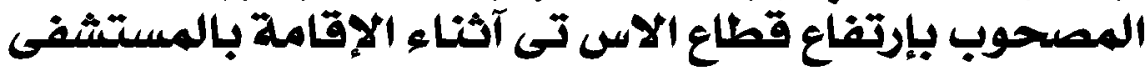

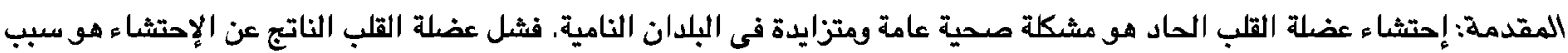

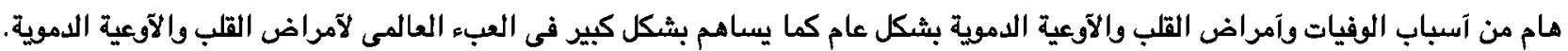

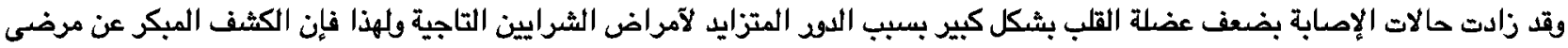
إحتشاء عضلة القلب الحاد المعرضين لخطر فشل عضلة القلب آثناء فترة حجزهم بالمستشفى هو ضرودى للحد من إصابة عضلة القلب وإختلال وظيفتها.

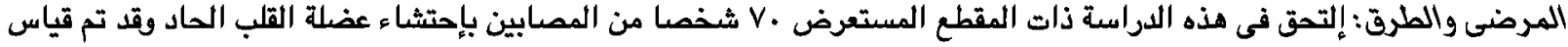

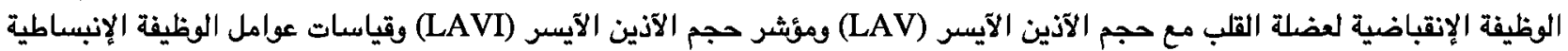

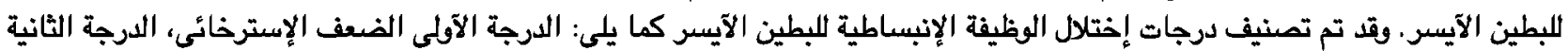
الضعف شبه الطبيعى الكاذب والدرجة الثالثة نمط التدفق الميترالى المقيد.

الإستتاجات: لعبت مؤشر حجم الآذين الآيسر (LAVI) وغيرها من العوامل المحددة المهام الإنقباضية والإنبساطية لعضلة القلب دورا

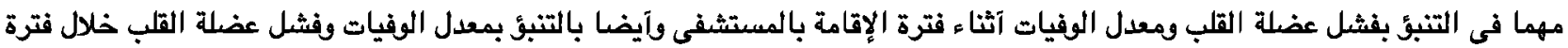

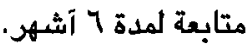

وقد آظهرت الدراسة آن مؤشر حجم الآذين الآيسر ويفة العضلة الإنقباضية ونسبة 'E/e خاصة هى آكثر المؤشرات التى تتنباً بحدوث

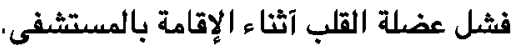

بينما كان مؤشر حجم الآنين الآيسر مؤشرا قويا لحلقث وفيات آثناء فترة المتابعة البالغة ستة آشهر وكانت وظيفة عضلة القلب الإنقباضية هى آهم مؤشر لحدوث آعراض قصور القلب بنفس فترة المتابعة. 